\title{
GROWTH AND NUTRIENT ACCUMULATION BY EICCHORNIA CRASSIPES (MART.) SOLMS IN ROBERTSON LAKE, JABALPUR, INDIA
}

\author{
Sadhana Jaiswal \\ Department of Life Sciences \\ Pt. Ravishankar Shukla University, Raipur-492010, Chhattisgarh, India \\ E-mail: sadhana_jaiswal74@rediffmail.com
}

\begin{abstract}
Macrophytes play an important role in nutrient dynamics of the lake ecosystem. The aim of this study is to determine the growth pattern and to evaluate the nutrient accumulation capacity of water hyacinth [Eichhornia crassipes (Mart) Solms] growing in Robrtson Lake, Jabalpur. The paper is outcome of in situ experiment conducted in Robertson lake (which has a dense mat of water hyacinth), as well as laboratory microcosms experiment. Water hyacinth grew at an average rate of $3.85 \mathrm{~g} \mathrm{dw} \mathrm{m}^{-2} \mathrm{~d}$ and it accumulates $263 \mathrm{~kg} \mathrm{~N} \mathrm{ha}^{-1} \mathrm{yr}^{-1}$ and $67 \mathrm{~kg} \mathrm{P} \mathrm{ha}^{-1} \mathrm{yr}^{-1}$, respectively. The chemistry of lake water does not show any significant seasonal variation; however the growth of water hyacinth in laboratory microcosms removed $79 \%$ of $\mathrm{PO}_{4}-\mathrm{P}$ and $58 \% \mathrm{NO}_{3}-\mathrm{N}$ from the growth medium. Thus, the data reveal that water hyacinth stands growing in the lake highly buffered the water chemistry by reducing nutrient level, in spite of heavy nutrient load in the lake from domestic waste and factory effluent.
\end{abstract}

Key words: Water hyacinth, nutrient accumulation, aquatic ecosystem, Robertson lake.

\section{INTRODUCTION}

Macrophytes are common features of aquatic ecosystem. Accumulation of nutrients due to anthropological activities in aquatic ecosystem leads to eutrophication resulting into massive growth of macrophytes. Macrophytes play an important role in maintaining the ecosystem of the lake. In the past, most vascular aquatic plants were considered nuisance in waterbodies. However, there is growing interest in the potential use of some aquatic plants for waste water purification and use of resulting biomass for production of energy, feed, fiber and other products. In recent years, much works have reported the nutrient accumulation capacity of aquatic plants (Hoagland et al. 2001, Hu et al. 2008, Khan and Shah 2010). Eicchornia crassipes (Mart.) Solms is the most commonly used vascular aquatic plant in renovating sewage effluent (Rogers and Devis 1972, Ornes and Sutton 1975, Wolverton and McDonald 1979) and agricultural drainage (Reddy et al. 1982). This is a free floating aquatic plant in which roots play important role in removing nutrients (Reed 1995). It has tremendous capacity of absorbing nutrients and other substances from water (Boyd 1970) and hence brings the pollution load down. It is found more effective in removal of BOD, COD, nitrogen, phosphorus, organic carbon, 
suspended solids, phenols, pesticides, heavy metals, etc. from waste water (Gupta 1982).

Nutrient absorption by controlled population of water hyacinth might reduce concentration of nitrogen and phosphorus in eutrophic lake. Assuming four percent nitrogen and 0.4 percent phosphorus in tissues, Steward (1970) suggested that one ha of plants in subtropical region might remove up to $6000 \mathrm{~kg}$ nitrogen and $600 \mathrm{~kg}$ of phosphorus per year. Using more conservative values for growth and nutrient content, Boyd (1970) estimated potential uptake of nitrogen and phosphorus by water hyacinth in warm climate as 1,980 and $322 \mathrm{~kg} \mathrm{ha}^{-1}$, respectively. Rogers and Davis (1972), after measuring nutrient uptake by water hyacinth in growth chamber experiment, concluded that absorption by one ha of water hyacinth would exceed $2,500 \mathrm{~kg}$ of nitrogen and $700 \mathrm{~kg}$ phosphorus per year.

There is need to study deterioration of water quality and massive growth of water hyacinth in Robertson Lake due to excessive pollution load from wastewater from vehicle factory and residential wastes. Heavy pollution load may affect the structure and function of ecosystem. Thus the study of nutrient accumulation, i.e. $\mathrm{C}, \mathrm{N}$ and $\mathrm{P}$, by water hyacinth is meaningful to investigate the response of ecosystem to nutrient loading.

\section{MATERIALS AND METHODS}

Present study was performed in Robertson Lake, Jabalpur (M.P.) India. Jabalpur is situated almost in the centre of India $\left(23^{0} 6^{\prime}\right.$ to $23^{0} 10^{\prime}$ North, $79^{0} 53^{\prime}$ to $80^{0} 6^{\prime}$ East, $397 \mathrm{~m}$ amsl). The lake is located in the eastern part of Jabalpur and has an approximate area of $0.7 \mathrm{~km}^{2}$. Domestic waste from residential quarters near Government Engineering College and waste water from vehicle factory are drained into the lake. It has dense stand of water hyacinth and has covered $75 \%$ of its surface area. Other macrophytes that occur in this lake are Bergia capensis, Chara globularis, Hydrilla verticillata and Lemna minor.
The growth experiment commenced with the appearance of fresh and young water hyacinth plants in October. Five permanent plots (each of 1 $\mathrm{m}^{2}$ area) were fabricated in the lake with the help of bamboo poles and nylon rope. Each plot was subdivided into four quadrats (each of $0.25 \mathrm{~m}^{2}$ area) by nylon thread. Ten young water hyacinth plants, each weighing about $25 \mathrm{~g}$ fresh weight (fw), were placed in each of the 20 quadrats. Thus, the initial standing crop biomass, i.e. the density of plants, was about $1000 \mathrm{~g} \mathrm{fw} \mathrm{m}^{-2}$. Plants were sampled after every 10 days. On each sampling date, all the plants from one plot were carefully taken out, washed and weighed for fresh weight individually. Thereafter, one plant from each quadrat of the sampled plot was brought to laboratory, and the remaining plants were placed back in the respective quadrats. This sampling design ensured that the growth of plants in each plot was not disturbed for at least 50 days. Variation in the fresh weight of plants was measured as coefficient of variation $(\mathrm{CV})$. The data on $\mathrm{CV}$ show that variation in the growth of different plants within a plot was always less than $40 \%$ throughout the experiment. The edge effect, therefore, did not have any significant effect on the plant's growth. The sampled plants were washed thoroughly under tap water and dried at $105^{\circ} \mathrm{C}$ for $48 \mathrm{~h}$ in a hot air oven to determine its dry weight. The dried matter was processed for determining the tissue concentration of carbon, nitrogen and phosphorus by standard methods. The experiment was performed without any discontinuity and covered winter and summer seasons.

To quantify the rate of nutrient uptake by water hyacinth, two sets of 15 plastic containers (ca. 2 1), each containing 1.51 of Hoagland growth medium were prepared; The first set was incubated without plants (Blank). In the second set, one water hyacinth plant (ca. $15 \mathrm{~g}$ fw) was placed in each of 15 containers. Both the sets were incubated under direct sunlight and sampled after 0, 7, 14 and 21 days of incubation. The level of growth medium was maintained daily by addition of glass - 
sterilized distilled water. On each sampling date, the plants were analyzed for dry weight and tissue concentration of carbon, nitrogen and phosphorus.

During the growth of water hyacinth in the lake as well as in the laboratory, the physicochemical characteristics of lake water (collected from the root - water interface) and Hoagland growth medium were analyzed on each sampling date. The $\mathrm{pH}$ was determined by Systronic digital $\mathrm{pH}$ meter, dissolved oxygen, dissolved inorganic carbon, chemical oxygen demand, $\mathrm{PO}_{4}-\mathrm{P}$, and total phosphorus were estimated by standard methods (APHA 1985), $\mathrm{NO}_{3}-\mathrm{N}, \mathrm{NH}_{3}-\mathrm{N}$ and total organic nitrogen were measured by standard methods (NEERI 1988). The growth rate constant $(\mu)$ was calculated by fitting the values of dry weight with the equation: $w_{t}=w_{0} \cdot e^{\mu t}$, where $w_{t}$ is the weight after a growth period ' $t$ ' (in days), and $\mathrm{w}_{0}$ is the initial dry weight.

Standard statistical methods were employed to calculate mean and standard error of different variables. One way ANOVA followed by the Duncan's new multiple range test was used to determine the significant differences at 0.05 level of probability between the values of variable among different growth periods (Duncan 1955).

\section{RESULTS}

Water hyacinth stands in the lake grew at an average rate of $3.85 \mathrm{~g} \mathrm{dw} \mathrm{m}^{-2} \mathrm{day}^{-1}$. The growth rate was significantly higher during the summer season (i.e., February and May 1998) as compared with that during winter season (i.e., October 1997 and February 1998). The average rate of growth was $3.2 \mathrm{~g} \mathrm{dw} \mathrm{m}^{-2}$ day $^{-1}$ during winter in comparison with $4.6 \mathrm{~g} \mathrm{dw} \mathrm{m}^{-2}$ day $^{-1}$ during summer. Total biomass accumulated by the standing crop of water hyacinth was $823.08 \mathrm{~g} \mathrm{dw} \mathrm{m}^{-2}$ in 205 days of growth. The coefficient of variation in biomass of individual plants within sampling quadrats was always less than $35 \%$ during the investigation. The tissue concentration of carbon changed from $39 \%$ to $54 \%$ during the growth. It was significantly lower during winter season as compared to that during the summer season (Table 1).

Table 1. Changes in dry weight $\left(\mathrm{g} \mathrm{m}^{-2}\right)$ and tissue concentration of carbon $(\mathrm{C})$, nitrogen $(\mathrm{N})$ and phosphorus (P) ( $\mathrm{mg} \mathrm{g}^{-1} \mathrm{dw}$ ) in the standing crop of water hyacinth during its growth in the lake (value are $x \pm s e$ ).

\begin{tabular}{ccccc}
\hline Day & Dry wt & $\mathbf{C}$ & $\mathbf{N}$ & $\mathbf{P}$ \\
\hline 0 & $33.77 \pm 0.06 \mathrm{a}$ & $393.1 \pm 0.56 \mathrm{a}$ & $21.8 \pm 0.4 \mathrm{c}$ & $2.82 \pm 0.03 \mathrm{a}$ \\
10 & $86.42 \pm 0.84 \mathrm{~b}$ & $395.6 \pm 3.2 \mathrm{a}$ & $23.1 \pm 0.3 \mathrm{~d}$ & $3.12 \pm 0.04 \mathrm{a}$ \\
20 & $105.17 \pm 1.15 \mathrm{bc}$ & $395.9 \pm 4.41 \mathrm{a}$ & $22.7 \pm 0.7 \mathrm{~d}$ & $3.80 \pm 0.25 \mathrm{c}$ \\
30 & $128.18 \pm 3.65 \mathrm{c}$ & $401.6 \pm 2.8 \mathrm{a}$ & $21.7 \pm 0.5 \mathrm{c}$ & $4.92 \pm 0.16 \mathrm{ef}$ \\
40 & $156.58 \pm 6.33 \mathrm{c}$ & $405.3 \pm 5.4 \mathrm{a}$ & $22.2 \pm 0.5 \mathrm{~cd}$ & $5.04 \pm 0.06 \mathrm{ef}$ \\
50 & $216.97 \pm 2.07 \mathrm{~d}$ & $405.9 \pm 3.2 \mathrm{a}$ & $23.0 \pm 0.5 \mathrm{~d}$ & $5.50 \pm 0.24 \mathrm{f}$ \\
60 & $257.68 \pm 2.8 \mathrm{e}$ & $393.1 \pm 7.7 \mathrm{a}$ & $22.6 \pm 0.6 \mathrm{~d}$ & $5.70 \pm 0.49 \mathrm{f}$ \\
70 & $301.17 \pm 8.5 \mathrm{f}$ & $400.8 \pm 1.3 \mathrm{a}$ & $21.6 \pm 0.3 \mathrm{c}$ & $4.42 \pm 0.07 \mathrm{~d}$ \\
80 & $321.05 \pm 7.02 \mathrm{f}$ & $379.3 \pm 2.5 \mathrm{a}$ & $20.7 \pm 0.4 \mathrm{bc}$ & $4.47 \pm 0.06 \mathrm{de}$ \\
90 & $325.49 \pm 5.13 \mathrm{f}$ & $389.9 \pm 7.4 \mathrm{a}$ & $20.4 \pm 0.3 \mathrm{~b}$ & $4.86 \pm 0.33 \mathrm{ef}$ \\
100 & $333.04 \pm 3.67 \mathrm{f}$ & $407.6 \pm 6.4 \mathrm{a}$ & $20.0 \pm 0.2 \mathrm{ab}$ & $5.43 \pm 0.56 \mathrm{f}$ \\
110 & $389.49 \pm 4.82 \mathrm{~g}$ & $389.2 \pm 1.4 \mathrm{a}$ & $20.3 \pm 0.1 \mathrm{~b}$ & $5.34 \pm 0.33 \mathrm{f}$ \\
120 & $457.02 \pm 6.39 \mathrm{~h}$ & $413.6 \pm 1.9 \mathrm{a}$ & $20.0 \pm 0.2 \mathrm{ab}$ & $4.41 \pm 0.20 \mathrm{~d}$ \\
135 & $503.66 \pm 13.5 \mathrm{i}$ & $503.6 \pm 4.2 \mathrm{bc}$ & $19.9 \pm 0.1 \mathrm{ab}$ & $3.92 \pm 0.91 \mathrm{c}$ \\
150 & $533.67 \pm 17.3 \mathrm{ij}$ & $542.5 \pm 2.4 \mathrm{c}$ & $19.3 \pm 0.1 \mathrm{ab}$ & $4.46 \pm 0.42 \mathrm{de}$ \\
165 & $546.13 \pm 6.7 \mathrm{j}$ & $545.5 \pm 5.4 \mathrm{c}$ & $19.0 \pm 0.1 \mathrm{a}$ & $4.71 \pm 0.14 \mathrm{de}$ \\
180 & $630.40 \pm 5.02 \mathrm{k}$ & $535.5 \pm 5.4 \mathrm{c}$ & $19.0 \pm 0.1 \mathrm{a}$ & $5.24 \pm 0.06 \mathrm{f}$ \\
195 & $704.49 \pm 2.29 \mathrm{l}$ & $539.2 \pm 5.1 \mathrm{c}$ & $18.8 \pm 0.1 \mathrm{a}$ & $4.75 \pm 0.18 \mathrm{e}$ \\
205 & $823.08 \pm 5.47 \mathrm{~m}$ & $490.7 \pm 3.3 \mathrm{~b}$ & $18.9 \pm 0.1 \mathrm{a}$ & $4.60 \pm 0.14 \mathrm{de}$ \\
\hline
\end{tabular}

Data which differ significantly between periods at the $\mathrm{p}=0.05$ are indicated by different letters (by Duncan's New Multiple Range Test). 
A slow rate of storage of carbon by the standing biomass was observed during winters, which became fast during summer months (Fig. 1). Total carbon storage by the standing crop was $404.2 \mathrm{~g} \mathrm{C} \mathrm{m}^{-2}$ during 205 days of growth. The tissue concentration of nitrogen recorded a reverse trend of seasonal change as that of carbon and decreased from $2.3 \%$ to $1.9 \%$ during the growth. However, the storage rate of nitrogen by the standing crop was relatively faster during summers as compared with that during winters (Fig. 1). Total accumulation of nitrogen by the standing crop was $15.59 \mathrm{~g} \mathrm{~N} \mathrm{~m}^{-2}$ in 205 days of growth. The tissue concentration of phosphorus did not show any definite pattern of seasonal change during the growth (Table 1). Total phosphorus accumulated by the standing biomass was $3.98 \mathrm{~g} \mathrm{P} \mathrm{m}^{-2}$ during 205 days of growth. The growth and storage rate constants of dry weight, carbon, nitrogen and phosphorus were $0.012,0.014,0.011$ and 0.013 day $^{-1}$, respectively. The growth pattern of standing crop biomass and storage pattern of $\mathrm{C}, \mathrm{N}$ and $\mathrm{P}$ were explained well by a simple exponential curve (Table 2).

Table 2. Average rates of growth and storage of carbon, nitrogen and phosphorus during growth of water hyacinth in the lake.

\begin{tabular}{lcccc}
\hline Variable & $\mathbf{n}$ & \multicolumn{2}{c}{ day $^{-1}$} & cd \\
& & $\boldsymbol{\mu}$ & se & \\
\hline $\mathrm{dw}$ & 76 & 0.012 & 0.0012 & 0.855 \\
$\mathrm{C}$ & 76 & 0.014 & 0.0011 & 0.904 \\
$\mathrm{~N}$ & 76 & 0.011 & 0.0012 & 0.824 \\
$\mathrm{P}$ & 76 & 0.013 & 0.0018 & 0.758 \\
\hline
\end{tabular}

$\mathrm{n}=$ number of observations; $\mu=$ growth rate constant; se $=$ standard error of $\mu$; $\mathrm{cd}=$ coefficient of determination, $\mathrm{dw}=$ dry weight

The chemistry of lake water was also studied during the growth of water hyacinth. Water temperature ranged from 15 to $30^{\circ} \mathrm{C}$ during the investigation period. It was minimum during December and January, becoming maximum during April and May. The $\mathrm{pH}$ changed narrowly from 7.1 to 7.75 without any significant seasonal variation during the investigation (Fig. 2). Dissolved oxygen (DO) ranged from 2.5 to $8 \mathrm{mg} \mathrm{l}^{-1}$ and the water-column remained unsaturated during most part of investigation period (Fig. 2). Dissolved inorganic carbon (DIC) ranged from 21.6 to $38.6 \mathrm{mg} \mathrm{l}^{-1}$ during the growth (from October 1997 to May 1998). The seasonal variation in DIC was insignificant. The dissolved chemical oxygen demand (dCOD) and particulate chemical oxygen demand (pCOD) did not follow any definite pattern of seasonal change (Table 3 ). $\mathrm{PO}_{4}$ - $\mathrm{P}$ ranged from 36.6 to $161 \mu \mathrm{g} \mathrm{l^{-1 }}$ during the growth period. The magnitude of periodic variations was very high during winter season and very low during summer season. Dissolved organic phosphorus (dOP) ranged from 14.8 to $133.7 \mu \mathrm{g} \mathrm{l}^{-1}$ and particulate organic phosphorus (pOP) ranged from 19.4 to $145.2 \mu \mathrm{g} \mathrm{l}^{-1}$ during the growth. It was significantly lower during summer months than that during the winter months (Table 3). Both dissolved as well as particulate fractions contributed equally to the total organic phosphorus. $\mathrm{NO}_{3}-\mathrm{N}$ changed narrowly from 0.20 to $0.64 \mathrm{mg} \mathrm{l}^{-1}$ during the growth. The periodic variation in $\mathrm{NO}_{3}-\mathrm{N}$ concentration was maximum during winter and minimum during summer season. $\mathrm{NH}_{3}-\mathrm{N}$ ranged from 0.48 to $1.96 \mathrm{mg} \mathrm{l}^{-1}$ during growth. A relatively high concentration of $\mathrm{NH}_{3}-\mathrm{N}$ was recorded during the summer months as compared to that during the winter months (Fig. 2). In the most of investigation period, a trace amount of $\mathrm{NO}_{2}-\mathrm{N}$ was recorded. Dissolved organic nitrogen $(\mathrm{dON})$ ranged from 0.15 to $0.67 \mathrm{mg} \mathrm{l}^{-1}$ and particulate organic nitrogen ( $\mathrm{pON}$ ) changed narrowly form 0.15 to $0.34 \mathrm{mg} \mathrm{l}^{-1}$ during the growth. Both dissolved as well as particulate fractions contributed equally to the total organic nitrogen (Table 3). 

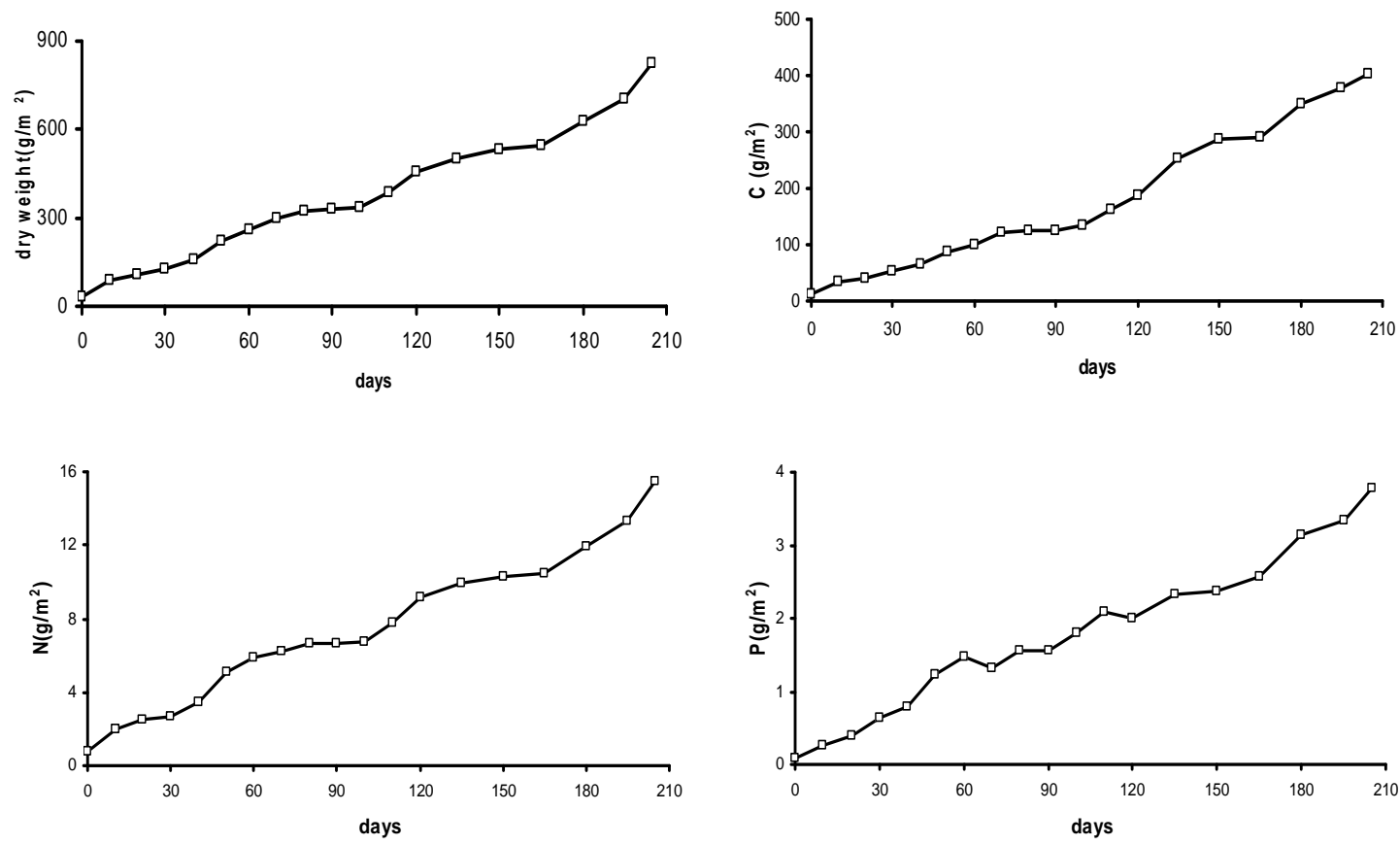

Fig. 1. Periodic changes in biomass, carbon, nitrogen and phosphorus $\left(\mathrm{g} \mathrm{m}^{-2}\right)$ of water hyacinth plant during its growth in the lake.
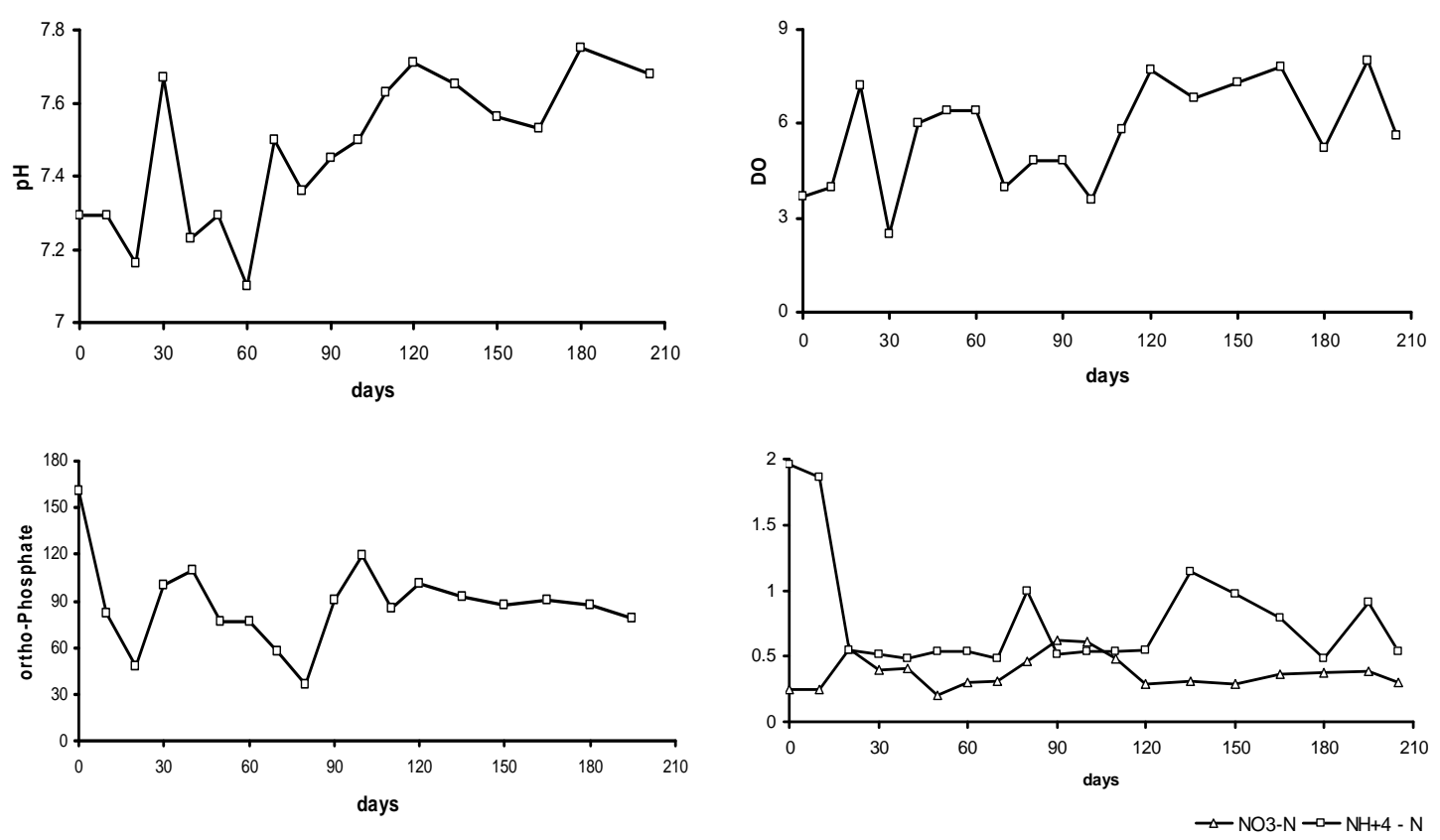

Fig. 2. Periodic changes in $\mathrm{pH}$ (units), dissolved oxygen $\left(\mathrm{mg} \mathrm{l}^{-1}\right), \mathrm{PO}_{4}-\mathrm{P}\left(\mu \mathrm{g} \mathrm{l}^{-1}\right), \mathrm{NO}_{3}-\mathrm{N}_{\text {and }} \mathrm{NH}_{3}-\mathrm{N}$ $\left(\mathrm{mg} \mathrm{l}^{-1}\right.$ ) of water during water hyacinth growth in the lake. 
Table 3. Changes in chemical oxygen demand $\left(\mathrm{mg} \mathrm{l}^{-1}\right)$, organic phosphorus $\left(\mu \mathrm{g} \mathrm{l}^{-1}\right)$ and organic nitrogen $\left(\mathrm{mg} \mathrm{l}^{-1}\right)$ of lake water during growth of water hyacinth.

\begin{tabular}{ccccccc}
\hline days & dCOD & pCOD & dOP & pOP & dON & pON \\
\hline 0 & $16.00 \pm 0.00 \mathrm{a}$ & $28.00 \pm 0.00 \mathrm{fg}$ & $120.4 \pm 2.4 \mathrm{gh}$ & $106.7 \pm 0.4 \mathrm{fg}$ & $0.15 \pm 0.00 \mathrm{a}$ & $0.27 \pm 0.00 \mathrm{c}$ \\
20 & $22.67 \pm 1.33 \mathrm{c}$ & $10.67 \pm 1.33 \mathrm{a}$ & $102.2 \pm 0.7 \mathrm{fg}$ & $145.212 .6 \mathrm{j}$ & $0.40 \pm 0.00 \mathrm{fg}$ & $0.16 \pm 0.00 \mathrm{a}$ \\
40 & $24.00 \pm 0.00 \mathrm{~d}$ & $12.00 \pm 0.00 \mathrm{a}$ & $63.5 \pm 1.3 \mathrm{~cd}$ & $91.22 .5 \mathrm{ef}$ & $0.42 \pm 0.04 \mathrm{~g}$ & $0.15 \pm 0.02 \mathrm{a}$ \\
60 & $36.00 \pm 0.00 \mathrm{~g}$ & $20.00 \pm 0.00 \mathrm{~b}$ & $32.2 \pm 6.6 \mathrm{~b}$ & $29.04 .5 \mathrm{a}$ & $0.67 \pm 0.00 \mathrm{n}$ & $0.23 \pm 0.00 \mathrm{~b}$ \\
80 & $22.67 \pm 1.33 \mathrm{c}$ & $36.00 \pm 0.02 \mathrm{hi}$ & $69.4 \pm 1.8 \mathrm{ef}$ & $21.56 .8 \mathrm{a}$ & $0.33 \pm 0.00 \mathrm{e}$ & $0.34 \pm 0.00 \mathrm{de}$ \\
100 & $32.00 \pm 0.00 \mathrm{f}$ & $28.00 \pm 0.00 \mathrm{fg}$ & $133.7 \pm 8.6 \mathrm{hi}$ & $79.11 .7 \mathrm{de}$ & $0.34 \pm 0.01 \mathrm{e}$ & $0.33 \pm 0.00 \mathrm{de}$ \\
120 & $20.00 \pm 0.00 \mathrm{~b}$ & $22.67 \pm 1.33 \mathrm{bc}$ & $130.6 \pm 1.9 \mathrm{gh}$ & $19.41 .2 \mathrm{a}$ & $0.36 \pm 0.00 \mathrm{ef}$ & $0.20 \pm 0.00 \mathrm{~b}$ \\
150 & $29.33 \pm 1.33 \mathrm{e}$ & $16.00 \pm 0.00 \mathrm{a}$ & $14.8 \pm 0.4 \mathrm{a}$ & $25.2 \pm 1.0 \mathrm{a}$ & $0.36 \pm 0.00 \mathrm{ef}$ & $0.31 \pm 0.00 \mathrm{~d}$ \\
180 & $24.00 \pm 0.00 \mathrm{~d}$ & $28.00 \pm 0.00 \mathrm{fg}$ & $39.8 \pm 0.7 \mathrm{~b}$ & $46.3 \pm 1.0 \mathrm{c}$ & $0.28 \pm 0.00 \mathrm{~d}$ & $0.22 \pm 0.00 \mathrm{~b}$ \\
205 & $20.00 \pm 0.00 \mathrm{~b}$ & $32.0 \pm 0.00 \mathrm{gh}$ & $40.7 \pm 1.3 \mathrm{bc}$ & $31.1 \pm 0.7 \mathrm{a}$ & $0.34 \pm 0.01 \mathrm{e}$ & $0.29 \pm 0.00 \mathrm{~cd}$ \\
\hline
\end{tabular}

Data which differ significantly between periods at the $\mathrm{p}=0.05$ are indicated by different letters (By Duncan's New Multiple Range Test). dCOD = Dissolved Chemical Oxygen Demand, pCOD = Particulate Chemical Oxygen Demand, dOP = Dissolved Organic Phosphorus, $\mathrm{POP}=$ Particulate Organic Phosphorus, $\mathrm{dON}=$ Dissolved Organic Nitrogen, pON = Particulate Organic Nitrogen.
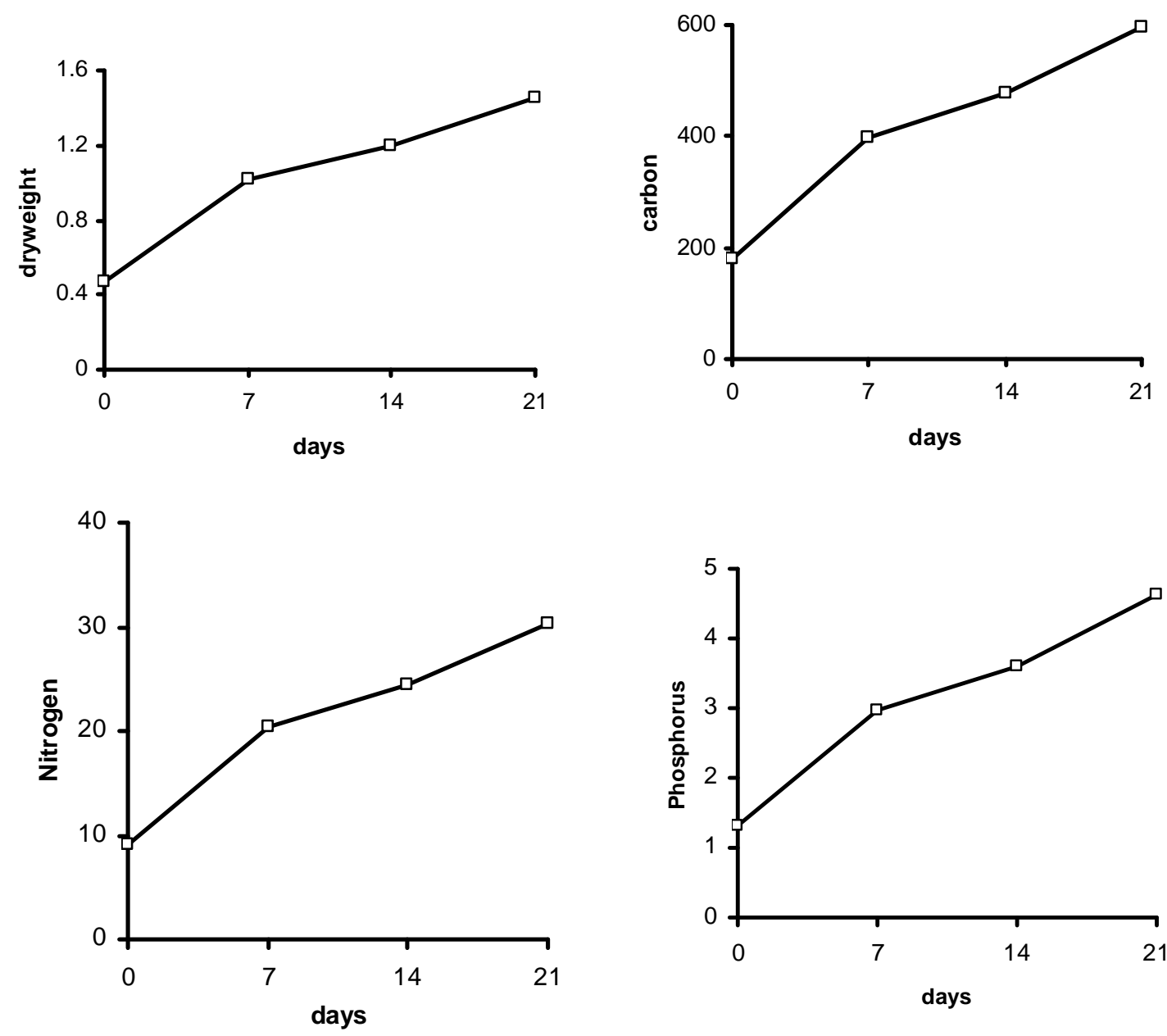

Fig. 3. Changes in dry weight $\left(\right.$ g plant $\left.^{-1}\right)$, carbon, nitrogen and phosphorus $\left(\mathrm{mg} \mathrm{plant}^{-1}\right)$ of water hyacinth during its growth in Hoagland medium. 
In the laboratory microcosm, young water hyacinth plants grew exponentially. Average growth rate of plants was $0.042 \mathrm{~g} \mathrm{dw}_{\text {plant }}{ }^{-1}$ day $^{-1}$. Average specific growth and storage rate constants of C, N and P were 0.042, 0.044, 0.046 and 0.051 day $^{-1}$, respectively. However, the differences between storage rate constants were statistically insignificant. Accumulation of dry weight, C, N and $\mathrm{P}$ in the growing plants was explained well by a simple exponential curve (Table 4). The average rate constant of phosphorus storage was significantly higher than that of carbon and nitrogen. The later recorded comparable values of rate constant, and were also comparable to the average growth rate constant. The doubling time required for dry weight, $\mathrm{C}, \mathrm{N}$ and $\mathrm{P}$ was $17,16,15$ and 14 days, respectively.

Changes in the chemistry of Hoagland medium were also measured during the plant growth (Fig. 3 ). The change in $\mathrm{pH}$ was very small that remained near neutral. The dissolved oxygen changed slightly from 10.53 to $9.07 \mathrm{mg} \mathrm{l}^{-1}$. The DIC decreased significantly from 30.55 to $16.4 \mathrm{mg} \mathrm{l}^{-1}$. A noticeable increase in COD was observed from 10.66 to $48 \mathrm{mg} \mathrm{l}^{-1}$, and the $\mathrm{PO}_{4}-\mathrm{P}$ decreased rapidly from 23.1 to $4.9 \mathrm{mg} \mathrm{l}^{-1}$. The rate of removal of $\mathrm{PO}_{4}-\mathrm{P}$ was maximum initially between day 0 and 7 becoming minimum during the later phase of growth, i.e., between day 7 and 21. Both the dissolved and particulate organic phosphorus increased from 0.83 to $4.6 \mathrm{mg} \mathrm{l}^{-1}$ and 0.38 to 2.51 $\mathrm{mg} \mathrm{l}^{-1}$, respectively. $\mathrm{NO}_{3}-\mathrm{N}$ decreased sharply from 67.19 to $27.99 \mathrm{mg} \mathrm{l}^{-1}$. The removal rate of $\mathrm{NO}_{3}-\mathrm{N}$ was minimum initially between day 0 and 7 and then increased becoming maximum during the later phase between day 14 and 21 . The net changes of $\mathrm{NO}_{2}-\mathrm{N}, \mathrm{NH}_{3}-\mathrm{N}, \mathrm{dON}$ and $\mathrm{pON}$ in the medium during the growth were negligible (Table 5).

Table 4. Average rates of growth and storage of carbon, nitrogen and phosphorus during growth in Hoagland medium.

\begin{tabular}{ccccc}
\hline Variable & $\mathbf{n}$ & \multicolumn{2}{c}{ day $^{-1}$} & cd \\
& & $\boldsymbol{\mu}$ & se & \\
\hline $\mathbf{d w}$ & 12 & 0.042 & 0.0036 & 0.985 \\
$\mathbf{C}$ & 12 & 0.044 & 0.0033 & 0.990 \\
$\mathbf{N}$ & 12 & 0.0 .46 & 0.0035 & 0.998 \\
$\mathbf{P}$ & 12 & 0.051 & 0.0025 & 0.995 \\
\hline
\end{tabular}

$\mathrm{n}=$ number of observations; $\mu=$ growth rate constant; se $=$ standard error of $\mu$; $\mathrm{cd}=$ coefficient of determination, $\mathrm{dw}=$ dry weight.

Table 5. Changes in chemistry of Hoagland medium $\left(\mathrm{mg} \mathrm{l}^{-1}\right)$, during growth of water hyacinth in laboratory microcosms.

\begin{tabular}{lcccc}
\hline variable & 0 day & $\mathbf{7 ~ d a y}$ & $\mathbf{1 4}$ day & 21 day \\
\hline $\mathrm{pH}$ (unit) & $7.26 \pm 0.00 \mathrm{a}$ & $7.99 \pm 0.03 \mathrm{a}$ & $8.53 \pm 0.13 \mathrm{a}$ & $8.59 \pm 0.48 \mathrm{~b}$ \\
$\mathrm{DO}$ & $10.53 \pm 0.13 \mathrm{e}$ & $8.93 \pm 0.13 \mathrm{a}$ & $8.53 \pm 0.13 \mathrm{a}$ & $9.07 \pm 0.13 \mathrm{~b}$ \\
$\mathrm{DIC}$ & $30.55 \pm 0.33 \mathrm{a}$ & $18.07 \pm 0.15 \mathrm{e}$ & $16.43 \pm 0.18 \mathrm{e}$ & $16.38 \pm .22 \mathrm{e}$ \\
$\mathrm{dCOD}$ & $6.66 \pm 1.33 \mathrm{a}$ & $17.33 \pm 1.33 \mathrm{~d}$ & $24.00 \pm 0.00 \mathrm{f}$ & $24.00 \pm 0.00 \mathrm{f}$ \\
$\mathrm{pCOD}$ & $4.00 \pm 1.33 \mathrm{a}$ & $5.54 \pm 1.33 \mathrm{a}$ & $5.33 \pm 1.33 \mathrm{a}$ & $24.00 \pm 0.00 \mathrm{f}$ \\
$\mathrm{PO}_{4}-\mathrm{P}$ & $23.14 \pm 0.65 \mathrm{a}$ & $10.35 \pm 0.15 \mathrm{k}$ & $5.49 \pm 0.17 \mathrm{p}$ & $4.83 \pm .03 \mathrm{pq}$ \\
$\mathrm{dOP}$ & $0.83 \pm 0.17 \mathrm{a}$ & $4.60 \pm 1.07 \mathrm{c}$ & $1.89 \pm 0.40 \mathrm{a}$ & $1.54 \pm .20 \mathrm{a}$ \\
$\mathrm{pOP}^{\mathrm{NO}}$ & $0.38 \pm 0.34 \mathrm{a}$ & $3.91 \pm 1.77 \mathrm{c}$ & $3.56 \pm 0.20 \mathrm{bc}$ & $3.32 \pm .31 \mathrm{~b}$ \\
$\mathrm{NO}_{3}-\mathrm{N}$ & $67.19 \pm 0.70 \mathrm{a}$ & $53.50 \pm .61 \mathrm{~h}$ & $38.67 \pm .30 \mathrm{o}$ & $27.99 \pm .61 \mathrm{u}$ \\
$\mathrm{NO}_{2}-\mathrm{N}$ & $2.29 \pm 0.00 \mathrm{w}$ & $2.52 \pm 0.00 \mathrm{y}$ & $0.00 \pm 0.00 \mathrm{a}$ & $2.96 \pm 0.03 \mathrm{z}$ \\
$\mathrm{NH}_{3}-\mathrm{N}$ & $0.00 \pm 0.00 \mathrm{a}$ & $1.92 \pm 0.00 \mathrm{~g}$ & $2.04 \pm .15 \mathrm{~h}$ & $2.64 \pm .07 \mathrm{j}$ \\
$\mathrm{dON}$ & $1.12 \pm 0.00 \mathrm{a}$ & $1.01 \pm 0.00 \mathrm{a}$ & $1.05 \pm .04 \mathrm{~b}$ & $1.14 \pm .07 \mathrm{a}$ \\
$\mathrm{pON}$ & $0.00 \pm 0.00 \mathrm{a}$ & $0.33 \pm 0.00 \mathrm{e}$ & $0.22 \pm .03 \mathrm{~d}$ & $0.20 \pm 0.00 \mathrm{~d}$ \\
\hline
\end{tabular}

Data which differ significantly between periods at the $\mathrm{p}=0.05$ are indicated by different letters (By Duncan's New Multiple Range Test). 


\section{DISCUSSION}

Water hyacinth plants have grown abundantly in Robertson Lake, covering nearly the whole surface area. Its production rates were from 0.44 to $7.79 \mathrm{~g} \mathrm{dw} \mathrm{m}^{-2} \mathrm{~d}^{-1}$ with an average of $3.85 \mathrm{~g} \mathrm{dw} \mathrm{m}^{-2}$ $\mathrm{d}^{-1}$ at the plant density from 34 to $823 \mathrm{~g} \mathrm{dw} \mathrm{m}^{-2}$. These values are relatively smaller than 9.2 to 11.7 $\mathrm{g} \mathrm{dw} \mathrm{m}^{-2} \mathrm{~d}^{-1}$, recorded earlier by some workers (Sharma 1990, DeBusk et al. 1981, Fitzsimons and Vallejos 1986). Water hyacinth productivity in natural water is generally a function of its density and eutrophic state of the habitat. The higher production rates have been recorded at high plant density of 15 to $35 \mathrm{~kg} \mathrm{fw} \mathrm{m}^{-2}$ with the maximum at a density of $1 \mathrm{~kg} \mathrm{dw} \mathrm{m} \mathrm{m}^{-2}$ (Lorber et al. 1984, Reddy and DeBusk 1985, DeBusk and Reddy 1987, Sharma 1990). The lower production values of the present study were basically due to a small initial plant density of $1 \mathrm{~kg} \mathrm{fw} \mathrm{m}^{-2}$ and not because of nutrition deficiency in the habitat. This was evident because the tissue $\mathrm{C}, \mathrm{N}$ and $\mathrm{P}$ concentrations as well as $\mathrm{C}: \mathrm{N}$ and $\mathrm{C}: \mathrm{P}$ ratios of the plants were similar to that reported for water hyacinth from the other eutrophic waters. Low productivity has led to a lower accumulation of $\mathrm{N}$ and $\mathrm{P}$ by the growing plants. The plants have accumulated only $263 \mathrm{~kg} \mathrm{~N} \mathrm{ha}^{-1} \mathrm{yr}^{-1}$ and $67 \mathrm{~kg} \mathrm{P}$ ha ${ }^{1} \mathrm{yr}^{-1}$ in comparison with the 1193 to $4782 \mathrm{~kg} \mathrm{~N}$ ha ${ }^{1} \mathrm{yr}^{-1}$ and 322 to $985 \mathrm{~kg} \mathrm{P} \mathrm{ha}^{-1} \mathrm{yr}^{-1}$ reported from the other eutrophic habitats and sewage effluents (Boyd 1970, Rogers and Davis 1972, Reddy and Tucker 1983, Reddy et al. 1982). The carbon concentration of tissues was generally greater during summer as compared to that during winter. This may be due to higher rates of dry mass production in the summer to that in the winters. In fact, the plant growth became almost static, when ambient air and water temperatures were minimum. The higher ambient air temperature and insolation generally sustain higher production rates (Reddy and Tucker 1983, Reddy and Sutton 1984, Reddy et al. 1982, Olga and Gaberscik 1989, Sharma
1990). However, the tissue $\mathrm{N}$ and $\mathrm{P}$ concentrations were generally greater during winter months in comparison with that observed during summer months (Table 1). Relatively slower growth in winter has caused a luxury uptake and faster summer growth has facilitated a dilution in the uptake of $\mathrm{N}$ and $\mathrm{P}$. As a consequence, the tissue $\mathrm{C}: \mathrm{N}$ and $\mathrm{C}: \mathrm{P}$ ratios were low in winter and high in summer.

Chemistry of lake water did not change seasonally, much in contrast to the distinct seasonality recorded for climatic and growth variables. The water - column remained neutral in $\mathrm{pH}$, under - saturated with $\mathrm{O}_{2}$ and enriched with inorganic $\mathrm{C}$ throughout the study period. These results have demonstrated that water hyacinth stands have significantly buffered the water chemistry. The dense mat of water hyacinth provided effective physical barriers for diffusion of atmospheric gases and light penetration for photosynthesis by phytoplankton and submerged macrophytes in the water - column. The exudates from this plant can also directly interfere with photosynthesis by phytoplankton (Sharma et al. 1996). Under such conditions, the main source of $\mathrm{O}_{2}$ in the water is its diffusion from the photosynthesizing plants, and that of $\mathrm{C}$ through the release of photosynthetic $\mathrm{C}$ and respiration by its roots. Aquatic macrophytes are known to add significant parts of their photosynthetic $\mathrm{C}$ and $\mathrm{O}_{2}$ in water via their roots (Gersberg et al. 1986, Reddy et al. 1982). Water hyacinths itself can add 2.4 to $10 \mathrm{~g} \mathrm{O}_{2} \mathrm{~m}^{-2} \mathrm{~d}^{-1}$ during its active growth (Moorhead and Reddy 1988). Therefore, higher release of photosynthetic $\mathrm{C}$ and $\mathrm{O}_{2}$ along with subsequent oxidation of organic $\mathrm{C}$ have resulted in a lower concentration regime of COD and a higher one of $\mathrm{O}_{2}$ during periods of active hyacinth growth in winter as well as summer. This was further evident by detection of very low $\mathrm{O}_{2}$ and relatively higher COD concentrations during a brief period of stagnated plant growth. Water hyacinth removed 
about $79 \%$ of $\mathrm{PO}_{4}-\mathrm{P}$ and $58 \% \mathrm{NO}_{3}-\mathrm{N}$ in 21 days of growth in the laboratory microcosms. These values are higher than earlier reported by Dhote (2007), where about $50 \%$ of $\mathrm{PO}_{4}-\mathrm{P}$ and $40 \% \mathrm{NO}_{3}-\mathrm{N}$ were removed by water hyacinth. These findings show that how water hyacinth buffered the water quality and play a significant role in nutrient dynamics of lake. Thus nutrient accumulation and removal efficiency by this plant can play an important role in eco-restoration of wetland ecosystem.

\section{ACKNOWLEDGEMENT}

The authors would like to acknowledge MPCST Bhopal India for partial financial support and Prof. R C. Rajak, Head, Department of Biological Sciences, RDVV Jabalpur for providing laboratory facilities.

\section{REFERENCES}

APHA (American Public Health Association). 1985. Standard Methods for the Examination of Water and Wastewater. $16^{\text {th }}$ Edition, APHA - AWWA - WPCI, Washington D.C., USA.

Boyd, C.E. 1970. Vascular aquatic plants for mineral nutrient removal from polluted waters. Economic Botany 24:95-103.

DeBusk, T.A., J.H. Ryther, M.D. Hanisack and L.D. Williams. 1981. Effect of seasonality and plant density on the productivity of some fresh water macrophytes. Aquatic Botany 10:133142.

DeBusk, W.F. and K.R. Reddy. 1987. Wastewater treatment using floating aquatic macrophytes: Contaminant removal processes and management strategies. In: Aquatic Plants for Water Treatment and Resource Recovery. (eds.) Reddy, K.R. and W.H. Smith. Mangolia Publications, Altamonte Springs, Florida. pp. 643-656.

Dhote, S. 2007. Role of macrophytes in improving water quality of an aquatic ecosystem. Journal of Applied Science and Environmental Management 11(4):133-135.
Duncan, D.B. 1955. Multiple range and multiple F tests. Biometrika 11:1-42.

Fitzsimons, R.E. and R.H. Vallejos. 1986. Growth of water hyacinth Eichhornia crassipes (Mart.) Solms. in middle Parana river (Argentina). Hydrobiologia 131:257-260.

Gersberg, R.M., B.V. Elkins, S.R. Lyon and C.R. Goldman. 1986. Role of aquatic plants in wastewater treatment by artificial wetlands. Water Research 20(3):363-368.

Gupta, G.C. 1982. Use of water hyacinth in waste water treatment. Journal of Environment Health 43(2):80-82.

Hoagland, C.R., L.E. Gentry and M.B. David. 2001. Plant nutrient uptake and biomass accumulation in a constructed wetland. Journal of Freshwater Ecology 16(4):527540.

Hu, M.H., Y.S. Ao, X.E. Yang and T.Q. Li. 2008. Treating eutrophic water for nutrient reduction using an aquatic macrophyte (Ipomoea aquatica Forsskal) in a deep flow technique system. Agriculture Water Management 95:607- 615 .

Khan, M.A. and M.A. Shah. 2010. Studies on biomass changes and nutrient lock up efficiency in a Kashmir Himalayan wetland ecosystem, India. Journal of Ecology and Natural Environment 2(8):147-153.

Lorber, M.N., J.W. Mishoe and P.R. Reddy. 1984. Modelling and analysis of water hyacinth biomass. Ecological Modeling 24:61-77.

Moorhead, K.K. and K.R. Reddy. 1988. Oxygen transport through selected aquatic macrophytes. Journal of Environmental Quality 17(1):138-142.

NEERI. 1988. Manual on Water and Waste Water Analysis. National Environmental Engineering Research Institute, Nagpur, India.

Olga, Urbanc-Bercic and A. Gaberscik. 1989. The influence of temperature and light intensity on activity of water hyacinth (Eichhornia crassipes (Mart.) Solms.) Aquatic Botany 35(3-4):403-408. 
Ornes, W.H. and D.L. Sutton. 1975. Removal of phosphorus from static sewage effluent by water hyacinths. Hyacinth Control Journal 13:56-58.

Reddy, K.R. and D.L. Sutton. 1984. Water hyacinths for water quality improvement and biomass production. Journal of Environmental Quality 13(1): 1-8.

Reddy, K.R. and J.C. Tucker. 1983. Productivity and nutrient uptake of water hyacinth, Echhornia crassipes. I. Effect of nitrogen source. Economic Botany 37(2):237-247.

Reddy, K.R. and W.F. DeBusk. 1985. Nutrient removal potential of selected aquatic macrophytes. Journal of Environmental Quality 14(4):459-462.

Reddy, K.R. and W.F. DeBusk. 1987. Nutrient storage capabilities of aquatic and wetland plants. In: Aquatic Plants for Water Treatment and Resource Recovery. (eds.) Reddy, K.R. and W.H. Smith. Mangolia Publ. Inc., Florida. pp. 337-357.

Reddy, K.R., K.L. Campbell, D.A. Greatz and K.M. Portier. 1982. Use of biological filters for agricultural drainage water treatment. Journal of Environmental Quality 11:591-595.

Reed, C. 1995. Natural Systems for Waste Management and Treatment. $2^{\text {nd }}$ Edition, Chapter 5. McGraw Hills Publications, New York, USA.

Rogers, H.H. and D.E. Davis. 1972. Nutrient removal by water hyacinth. Weed Science 2:423-428.

Sharma, A. 1990. Studies on Impact of Human Activities on the Trophic State of a Lake at Jabalpur. Ph.D. Thesis, R.D. University, Jabalpur, India.

Sharma, A., M.K. Gupta and P.K. Singhal. 1996. Toxic effect of leachate of water hyacinth decay on the growth of Senedesmus obliquus. Water Research 30(10):2281-2286.

Steward, K.K. 1970. Nutrient removal potential of various aquatic plants. Hyacinth Control Journal 8:34-35.

Wolverton, B.C. and R.C. McDonald. 1979. Water hyacinth (Eichhornia crassipes) productivity and harvesting studies. Economic Botany 33: $1-10$. 